\title{
molecules
}

ISSN 1420-3049

www.mdpi.com/journal/molecules

Article

\section{Vernonia kotschyana Roots: Therapeutic Potential via Antioxidant Activity}

Alexandru Vasincu ${ }^{1}$, Berit S. Paulsen ${ }^{2}$, Drissa Diallo ${ }^{3}$, Ioana Vasincu ${ }^{4}$, Ana C. Aprotosoaie ${ }^{1}$, Veronica Bild ${ }^{1}$, Christiana Charalambous ${ }^{5}$, Andreas I. Constantinou ${ }^{5}$, Anca Miron ${ }^{1, *}$ and Cristina M. Gavrilescu ${ }^{6, *}$

1 Department of Pharmaceutical Sciences II, Faculty of Pharmacy, University of Medicine and Pharmacy Grigore T. Popa-Iasi, Universitatii Str. 16, 700115 Iasi, Romania;

E-Mails: alexandru.vasincu@umfiasi.ro (A.V.); ana.aprotosoaie@umfiasi.ro (A.C.A.); veronica.bild@umfiasi.ro (V.B.)

2 Section of Pharmaceutical Chemistry, School of Pharmacy, University of Oslo, P.O. Box 1068 Blindern, N-0316 Oslo, Norway; E-Mail: b.s.paulsen@farmasi.uio.no

3 Department of Traditional Medicine, University of Bamako, PB 1746 Bamako, Mali; E-Mail: dri.diallo@yahoo.fr

4 Department of Pharmaceutical Sciences I, Faculty of Pharmacy, University of Medicine and Pharmacy Grigore T. Popa-Iasi, Universitatii Str. 16, 700115 Iasi, Romania;

E-Mail: ioana-mirela.vasincu@umfiasi.ro

5 Department of Biological Sciences, University of Cyprus, Kallipoleos 75, 1678 Nicosia, Cyprus; E-Mails: ccharala@hotmail.com (C.C.); andreasc@ucy.ac.cy (A.I.C.)

6 Department Medical I, Faculty of Medicine, University of Medicine and Pharmacy Grigore T. Popa-Iasi, Universitatii Str. 16, 700115 Iasi, Romania

* Authors to whom correspondence should be addressed; E-Mails: anca.miron@umfiasi.ro (A.M.); cristina.gavrilescu@umfiasi.ro (C.M.G.); Tel.: +40-232-301-600 (A.M.);

Fax: +40-232-211-820 (A.M.).

External Editor: Derek J. McPhee

Received: 10 August 2014; in revised form: 12 November 2014 / Accepted: 12 November 2014 / Published: 19 November 2014

\footnotetext{
Abstract: The roots of Vernonia kotschyana Sch. Bip. ex Walp. (Asteraceae) are used in Malian traditional medicine in the treatment of gastroduodenal ulcers and gastritis. Since oxidative stress is involved in gastric ulceration, the aim of this study was to screen the root extracts for their in vitro antioxidant activity and phenolic content. The roots were
} 
extracted successively with chloroform, ethyl acetate, ethanol and water. The antioxidant activity of root extracts was evaluated in both cell-free and cell-based assays. Their chemical characterization was performed by Fourier transform infrared spectroscopy (FT-IR) whereas the total phenolic content was determined by the Folin-Ciocalteu method. The ethyl acetate extract displayed the highest phenolic content and was found to be the most active in the free radical scavenging and lipid peroxidation inhibition assays; it also showed a high antioxidant activity in MCF-12F cells. This study suggests a potential use of the ethyl acetate extract of Vernonia kotschyana not only as an antioxidant agent in gastroduodenal ulcers and gastritis, but also in other disorders characterized by high levels of oxidative stress.

Keywords: Vernonia kotschyana; ethyl acetate extract; free radical scavenging activity; lipid peroxidation inhibition; FT-IR spectroscopy; phenolic content

\section{Introduction}

Gastric ulcers have been treated with herbal drugs for centuries. Ethnopharmacological surveys reveal numerous plant species used in the treatment of gastric ulcer. For many of them, pharmacological studies have elucidated the mechanisms of antiulcer activity thus justifying the traditional use. Anti-Helicobacter pylori, antisecretory, cytoprotective and antioxidant effects are mainly involved in the antiulcer activity of plant extracts $[1,2]$.

Reactive oxygen species (ROS) and, to a lesser extent, reactive nitrogen species (RNS) play a critical role in gastric ulceration. Helicobacter pylori, the main causative factor of gastric ulcers and gastritis, recruits neutrophils and macrophages to the site of infection where they release high levels of ROS (oxidative burst). First, superoxide anion radical is produced by membrane-associated nicotinamide adenine dinucleotide phosphate oxidase (NADPH oxidase). Superoxide anion radical can be further converted into hydrogen peroxide both enzymatically (via superoxide dismutases) and non-enzymatically. In the presence of transition metal ions (ferrous and cuprous ions), superoxide anion radical and hydrogen peroxide interact and form the highly reactive hydroxyl radical. Neutrophil myeloperoxidase generates hypochlorous acid from hydrogen peroxide and chloride anions; hypochlorous acid is a precursor of chloramines, oxidant and cytotoxic species. This overproduction of ROS is the major cause of gastric mucosal damage. In addition, Helicobacter pylori induces the expression of inducible nitric oxide synthase (iNOS) in the gastric mucosa thus promoting the generation of nitric oxide and peroxynitrite anion. The latter, produced by the reaction between nitric oxide and superoxide anion radical, is highly cytotoxic [3]. Some of these reactive species (hydroxyl radical, peroxynitrite anion) mediate lipid peroxidation processes with subsequent cell lysis and generation of cytotoxic products such as malondialdehyde and 4-hydroxynonenal [4,5]. Oxidative stress is also involved in the gastric ulcerations caused by ethanol, nonsteroidal anti-inflammatory drugs (NSAIDS) and cold restraint stress [6,7]. Many human studies support the involvement of oxidative stress in gastric ulcerations. Low levels of glutathione, high levels of malondialdehyde, changes in gastric mucosal superoxide dismutase and glutathione peroxidase activities and high levels 
of nitric oxide in gastric juice have been reported in patients with gastric ulcers. In addition, a decrease in serum levels of endogenous antioxidants (glutathione, vitamins $\mathrm{E}$ and $\mathrm{C}$ ) and an increase in serum level of malondialdehyde have been detected $[8,9]$.

The antiulcer activity of many plant extracts is largely related to their antioxidant potential. Besides its anti-Helicobacter pylori and cytoprotective effects, the aqueous extract of Zingiber officinale rhizome increased the level of reduced glutathione, decreased lipid peroxidation and normalized the activity of antioxidant enzymes (catalase, superoxide dismutase, glutathione peroxidase) in the gastric mucosa and serum in swim/ethanol stress-induced ulcer models [10]. Parkia speciosa ethanol leaf extract significantly decreased lipid peroxidation and increased the levels of glutathione and superoxide dismutase in the gastric mucosa in rats with ethanol-induced gastric ulcers. In addition, the extract showed the ability to upregulate the heat-shock protein 70 (HSP70) and downregulate the pro-apoptotic protein BAX, the former being involved in cytoprotection against different stresses, including oxidative stress [11]. The ethanol leaf extract of other Parkia species, P. platycephala, protected against ethanol-induced gastric lesions by different mechanisms including activation of catalase [12]. The gastroprotective effects of Opuntia ficus indica $f$. inermis flowers extract against ethanol-induced gastric mucosal damage were reported to be based on its antioxidant potential (inhibition of lipid peroxidation, protein oxidation, DNA fragmentation and myeloperoxidase activity, the latter being an index of neutrophil infiltration, restoration of the activities of superoxide dismutase, catalase and glutathione peroxidase) [13]. In different experimental models (water immersion stress, cold restraint stress, ethanol, aspirin, pylorus ligation-induced gastric ulcers in rats), extracts from strawberry cultivars (Fragaria $\times$ ananassa), Curcuma longa, Mentha piperita and Moringa oleifera were all reported to reduce gastric injury by decreasing lipid peroxidation and normalizing the activity of antioxidant enzymes [14-16].

The Vernonia genus (Asteraceae) includes around one thousand species distributed worldwide, mainly in the tropical regions. Many Vernonia species are used as foods ( . amygdalina, $V$. colorata) or herbal medicines ( $V$. amygdalina, $V$. condensata, $V$. conferta, $V$. cinerea, $V$. guineensis), and several species have industrial uses ( $V$. galamensis) [17]. The roots of Vernonia kotschyana Sch. Bip. ex Walp. syn. Baccharoides adoensis var. kotschyana (Sch. Bip. ex Walp.) are used in Malian traditional medicine in the treatment of gastrointestinal disorders (gastroduodenal ulcers, gastritis, indigestion) and wounds [18,19]. A Malian improved traditional medicine, Gastrosedal, consisting of the dried powdered roots, is recommended to be administered as a decoction in gastroduodenal ulcers and gastritis; a small clinical trial demonstrated its efficacy in gastric ulcer patients [18]. To our knowledge, only the biological effects of the root aqueous extracts and some of their constituents (polysaccharide fractions) have been investigated. The macerate was reported to reduce the number and severity of ethanol-induced gastric lesions in rats (hyperemia and thickened lesions of the mucosa) [20]. Acidic polysaccharide fractions containing type II arabinogalactan structures and inulin-rich fractions were isolated from the $50{ }^{\circ} \mathrm{C}$ and $100{ }^{\circ} \mathrm{C}$ water extracts. Acidic polysaccharides showed complement fixation and induction of B-cell proliferation effects; these immunomodulatory activities may, in part, explain an anti-inflammatory and tissue repair potential. Inulin-rich fractions showed no immunomodulating activities (complement fixation, macrophage activation) but reduced $0.3 \mathrm{M} \mathrm{HCl}-60 \%$ ethanol-induced gastric lesions in mice [18,19]. A recent study showed that the $100{ }^{\circ} \mathrm{C}$ crude water extract and two pectic polysaccharides inhibited Helicobacter pylori adhesion to gastric adenocarcinoma 
epithelial cells; the most potent activity (approximately 30\% decrease in Helicobacter pylori adherence) was detected for the arabinose-rich pectic polysaccharide [21]. As the roots of $V$. kotschyana are used to produce Gastrosedal, the wild populations have diminished considerably. Therefore, the plant is now cultivated in several areas in Mali. No significant differences were detected in the chemical composition, complement fixation and macrophages stimulation between polysaccharides from cultivated and wild $V$. kotschyana roots suggesting that the cultivated roots can replace wild ones in producing Gastrosedal and other herbal medicines [22].

Despite the fact that oxidative stress plays an important role in gastric ulceration, the antioxidant potential of $V$. kotschyana roots has not been investigated yet. In this respect, our goal was to evaluate the antioxidant potential of root extracts in relation to antiulcer activity and other pharmacological activities partially mediated by antioxidant effects. The present work reports data on the antioxidant activity of different extracts of $V$. kotschyana roots assessed by several in vitro assays.

\section{Results and Discussion}

Successive extractions of $V$. kotschyana roots with solvents of increasing polarity led to four extracts: chloroform (V-C), ethyl acetate (V-EA), ethanol (V-E) and aqueous (V-A) extracts; the yields were found to be $1.1 \%, 2.08 \%, 4.82 \%$ and $6.95 \%$, respectively.

\subsection{Free Radical Scavenging Activity}

The free radical scavenging effects of $V$. kotschyana extracts were initially evaluated against the synthetic nitrogen-centered 2,2'-azinobis(3-ethylbenzothiazoline-6-sulfonic acid (ABTS) radical cation [23]. At the highest concentration $(100 \mu \mathrm{g} / \mathrm{mL})$, ethyl acetate and ethanol extracts scavenged $97.30 \% \pm 0.18 \%$ and $84.65 \% \pm 0.56 \%$ of the radical, respectively. At the same concentration, chloroform and aqueous extracts showed weak scavenging effects $(18.07 \% \pm 0.24 \%$ and $16.95 \% \pm 0.20 \%$, respectively) while glutathione, the positive control, completely scavenged the radical (Figure 1a). According to the $\mathrm{EC}_{50}$ values, ethyl acetate extract $(20.59 \pm 0.07 \mu \mathrm{g} / \mathrm{mL})$ was the most active; glutathione scavenged the radical with an $\mathrm{EC}_{50}$ value of $3.25 \pm 0.02 \mu \mathrm{g} / \mathrm{mL}$ (Table 1). The ABTS scavenging activity of ethyl acetate extract was comparable to or better than that reported for different extracts of $V$. cinerea whole plant $\left(\mathrm{EC}_{50}=19.54-26.81 \mu \mathrm{g} / \mathrm{mL}\right)$ but inferior to that of ethanol extract of $V$. cinerea leaves $\left(\mathrm{EC}_{50}=12 \mu \mathrm{g} / \mathrm{mL}\right)$ [24,25]. There are also reports on extracts from other species (Cedrus brevifolia, Angelica sinensis) having higher ABTS scavenging potential $\left(\mathrm{EC}_{50}=2.3-11.9 \mu \mathrm{g} / \mathrm{mL}\right)[26,27]$. As glutathione is a powerful antioxidant, it is obvious that ethyl acetate extract, approximately six times less potent, is an efficient ABTS radical scavenger.

Further, the scavenging effects against superoxide, hydroxyl and nitric oxide radicals were evaluated [28-31]. Superoxide anion radical, generated by the autoxidation of pyrogallol [28,29], was efficiently scavenged only by the ethyl acetate extract. The superoxide scavenging activity of ethyl acetate extract increased dose-dependently from $7.11 \% \pm 0.52 \%$ at $241.93 \mu \mathrm{g} / \mathrm{mL}$ to $95.15 \% \pm 0.33 \%$ at $645.16 \mu \mathrm{g} / \mathrm{mL}$. At this concentration, chloroform, ethanol and aqueous extracts exhibited only $4.56 \% \pm 0.58 \%, 10.01 \% \pm 0.60 \%$ and $4.12 \% \pm 0.71 \%$ scavenging activity, respectively. 
Table 1. EC50 values of Vernonia kotschyana root extracts in different antioxidant assays.

\begin{tabular}{|c|c|c|c|c|c|c|c|}
\hline $\begin{array}{c}\text { Extract/Positive } \\
\text { Control }\end{array}$ & $\begin{array}{c}\text { ABTS Radical } \\
\text { Cation Scavenging } \\
\text { Activity * }\end{array}$ & $\begin{array}{c}\text { Superoxide Anion } \\
\text { Radical Scavenging } \\
\text { Activity * }\end{array}$ & $\begin{array}{l}\text { Hydroxyl Radical } \\
\text { Scavenging } \\
\text { Activity ** }\end{array}$ & $\begin{array}{c}\text { Nitric Oxide } \\
\text { Scavenging } \\
\text { Activity * }\end{array}$ & $\begin{array}{c}\text { Lipid Peroxidation } \\
\text { Inhibitory } \\
\text { Activity **** }\end{array}$ & $\begin{array}{c}\text { Ferrous Ion } \\
\text { Chelating } \\
\text { Activity **** }\end{array}$ & $\begin{array}{c}\text { Antioxidant } \\
\text { Activity in } \\
\text { MCF-12F Cells * }\end{array}$ \\
\hline V-C & n.d. & n.d. & n.d. & n.d. & $1.06 \pm 0.02 * *,, \mathrm{gg}$ & $3.33 \pm 0.03 * * \mathrm{i}$ & n.t. \\
\hline V-EA & $20.59 \pm 0.07^{\mathrm{a}, \mathrm{b}}$ & $370.42 \pm 0.67^{b}$ & $0.88 \pm 0.00^{\mathrm{a}, \mathrm{d}}$ & $55.50 \pm 0.27^{\mathrm{a}, \mathrm{e}}$ & $0.24 \pm 0.00 * *, \mathrm{~g}, \mathrm{~h}$ & n.d. & $144.46 \pm 2.57^{\mathrm{j}}$ \\
\hline V-E & $51.96 \pm 0.31^{\mathrm{b}, \mathrm{c}}$ & n.d. & $3.61 \pm 0.01^{\mathrm{e}, \mathrm{c}}$ & $127.63 \pm 0.84^{\mathrm{e}, \mathrm{c}}$ & n.d. & n.d. & n.d. \\
\hline V-A & n.d. & n.d. & n.d. & n.d. & n.d. & n.d. & n.t. \\
\hline Glutathione & $3.25 \pm 0.02^{\mathrm{c}, \mathrm{a}}$ & $31.21 \pm 0.07^{\mathrm{c}}$ & n.t. & n.d. & n.t. & n.t. & n.t. \\
\hline L-Ascorbic acid & n.t. & n.t. & $0.11 \pm 0.00^{\mathrm{f}, \mathrm{a}}$ & $46.00 \pm 0.24^{\mathrm{c}, \mathrm{a}}$ & n.t. & n.t. & n.t. \\
\hline DL- $\alpha$-Tocopherol acetate & n.t. & n.t. & n.t. & n.t. & $17.4 \pm 0.0 * \mathrm{kh, \textrm {c }}$ & n.t. & n.t. \\
\hline EDTA & n.t. & n.t. & n.t. & n.t. & n.t. & $6.18 \pm 0.08 *, \mathrm{~h}$ & n.t. \\
\hline Sodium pyruvate & n.t. & n.t. & n.t. & n.t. & n.t. & n.t. & $78.43 \pm 3.03^{\mathrm{c}}$ \\
\hline
\end{tabular}


Figure 1. (a) ABTS radical cation scavenging activity. (b) Superoxide anion radical scavenging activity. (c) Hydroxyl radical scavenging activity. (d) Nitric oxide scavenging activity. (e) Lipid peroxidation inhibitory activity. (f) Ferrous ion chelating activity. (g) Antioxidant activity in MCF-12F cells.

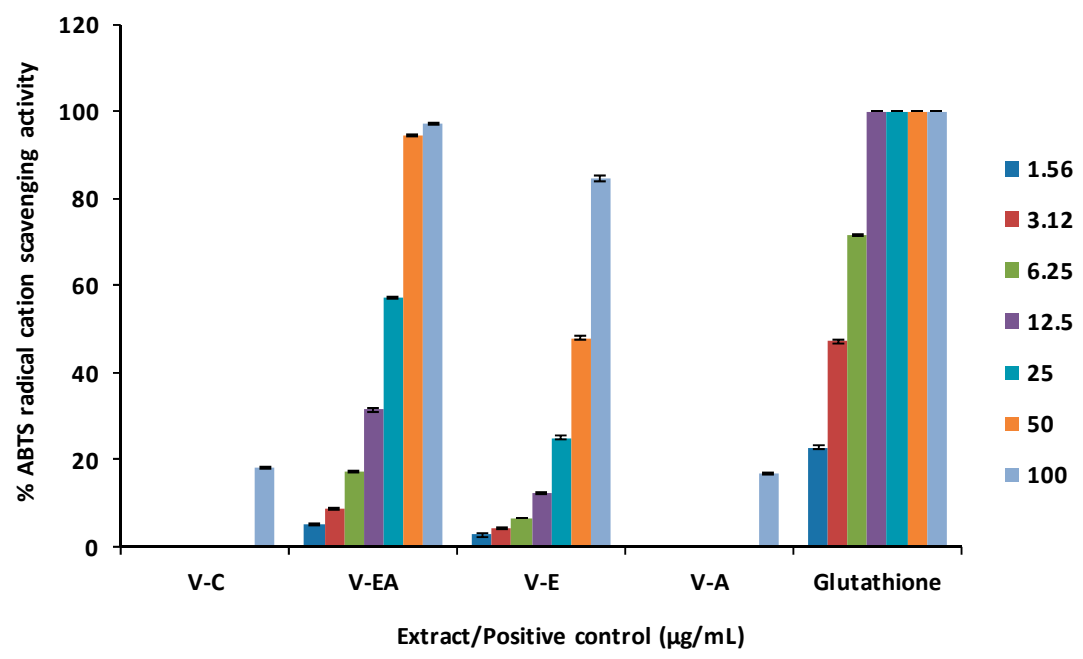

(a)

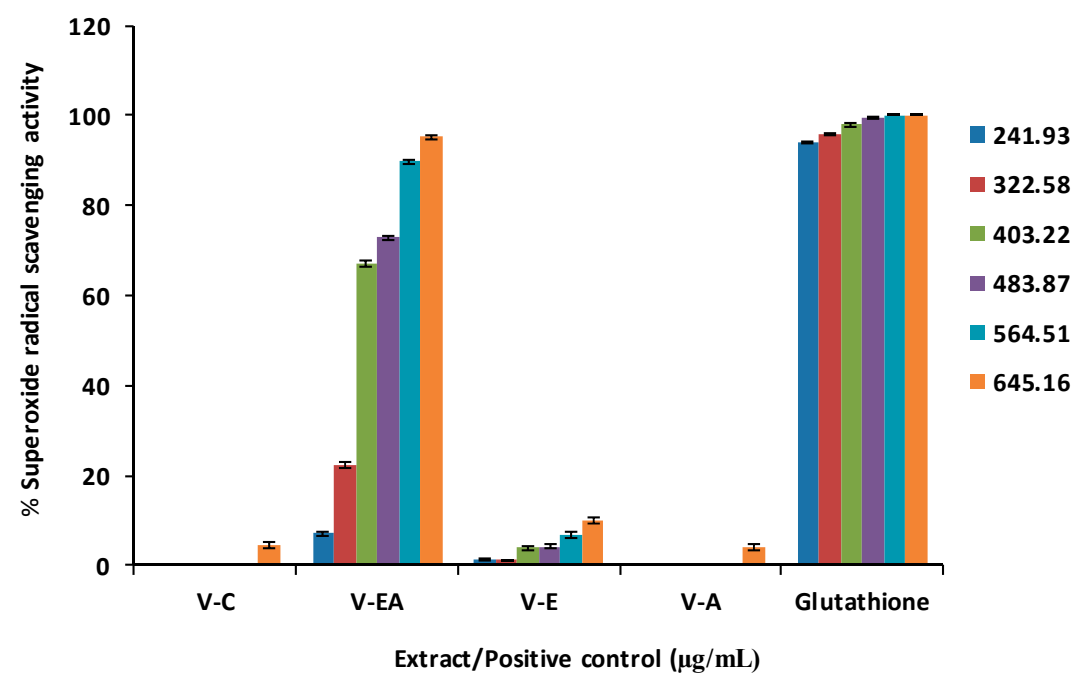

(b)

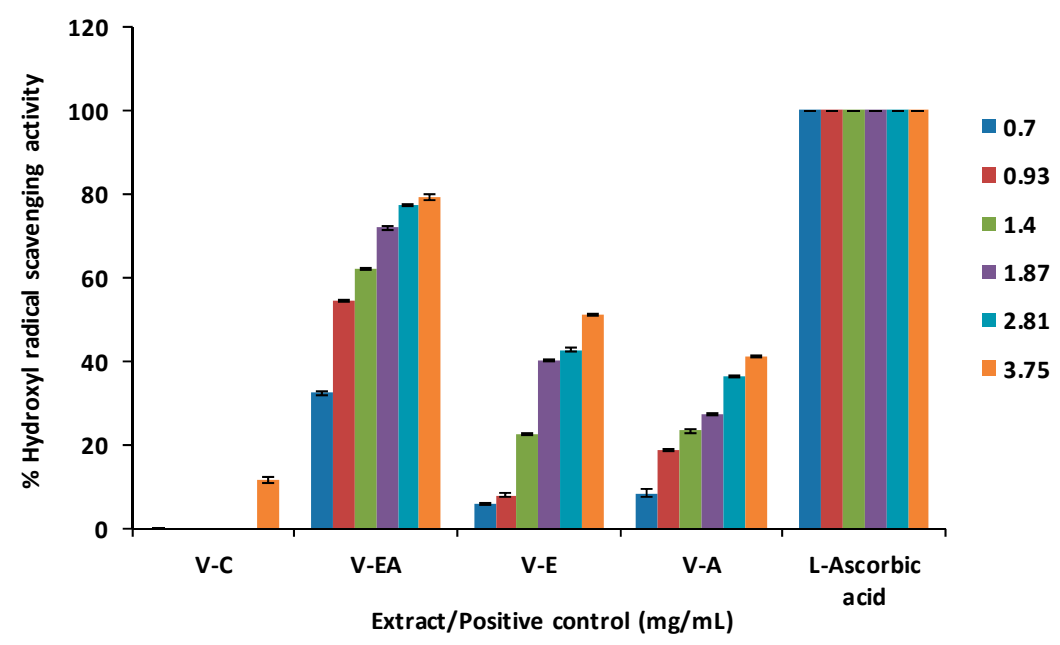

(c) 
Figure 1. Cont.

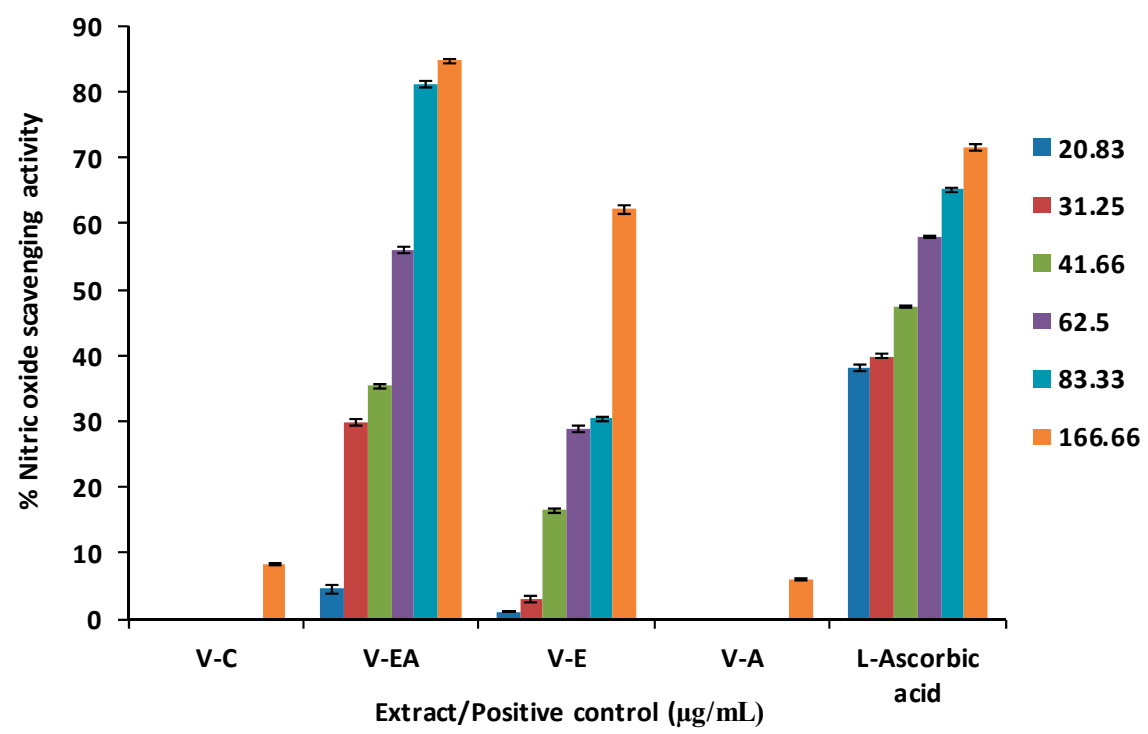

(d)

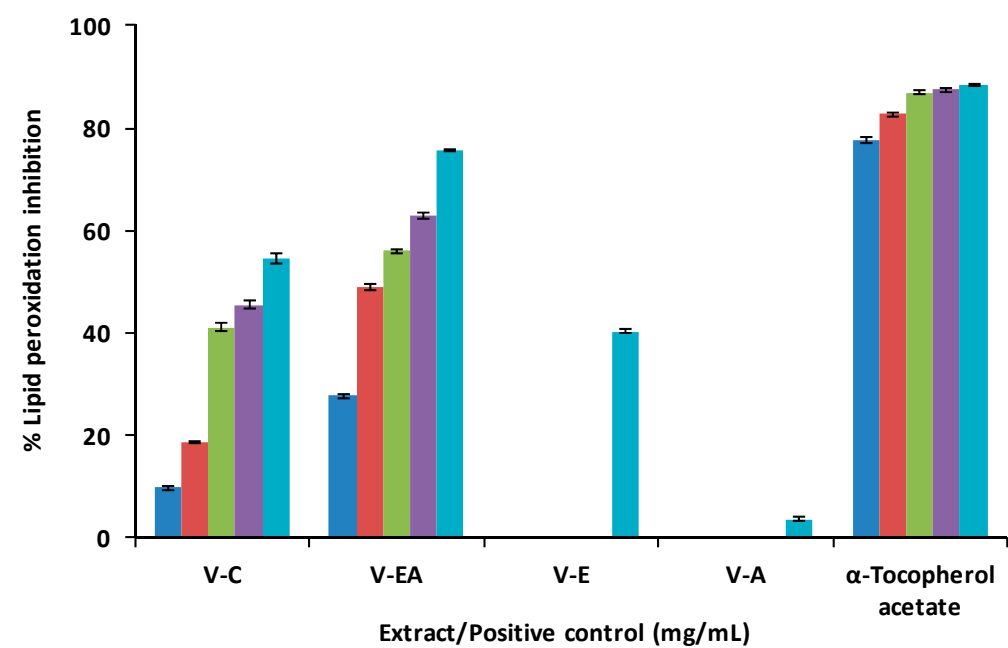

0.1

0.21

0.43

0.86

1.3

(e)

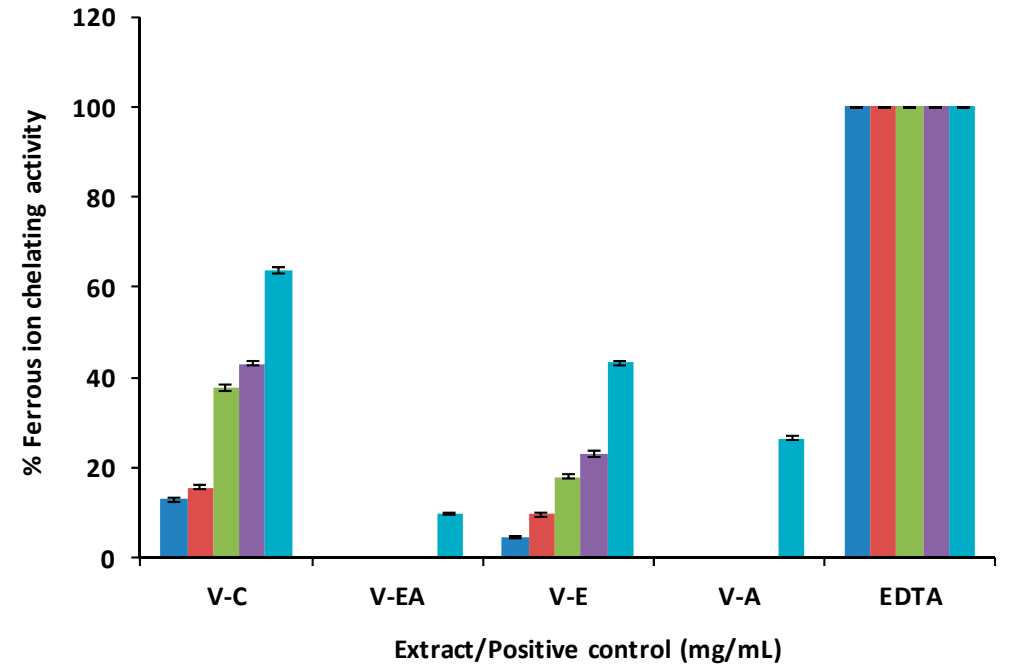

0.33

0.66

1.33

2.65

5.3

(f) 
Figure 1. Cont.

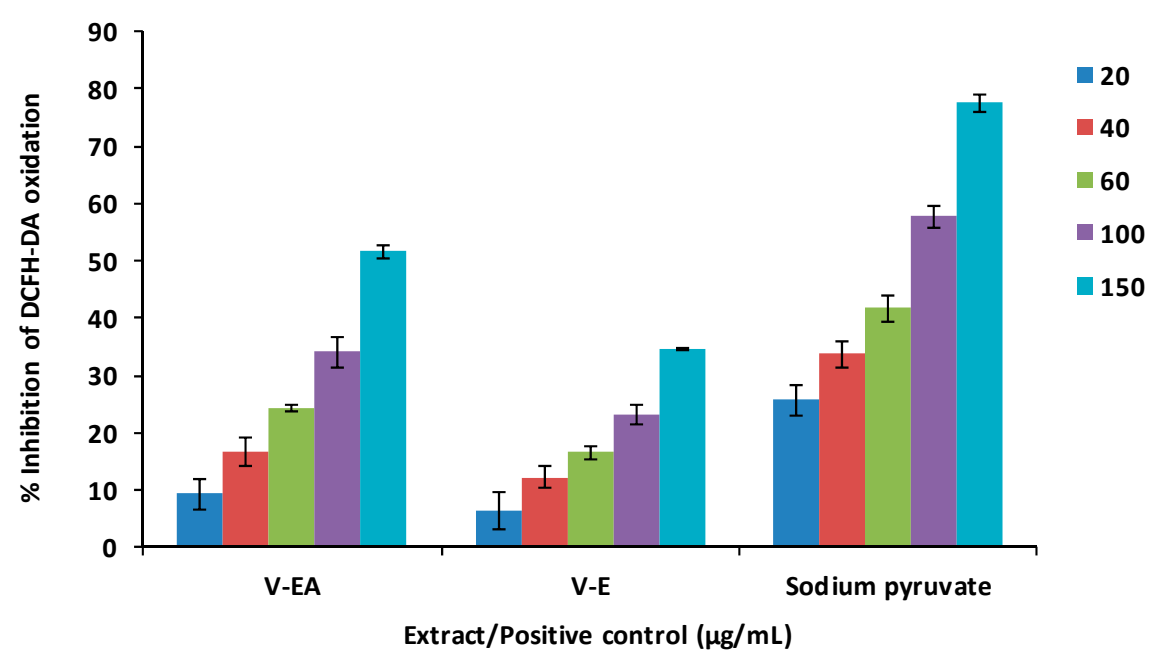

(g)

In the same concentration range $(241.93-645.16 \mu \mathrm{g} / \mathrm{mL})$, the scavenging effects of glutathione varied between $93.98 \% \pm 0.16 \%$ and $101.01 \% \pm 0.17 \%$ (Figure 1b). Hydroxyl radical, generated by Fenton reaction [30], was scavenged with different potencies by $V$. kotschyana extracts. At $3.75 \mathrm{mg} / \mathrm{mL}$, the scavenging percentages of chloroform, ethyl acetate, ethanol and aqueous extracts were $11.70 \% \pm 0.88 \%, 79.42 \% \pm 0.68 \%, 51.05 \% \pm 0.23 \%$ and $41.06 \% \pm 0.29 \%$, respectively. The positive control, L-ascorbic acid, scavenged hydroxyl radical more efficiently than $V$. kotschyana extracts; it completely scavenged the radical in the concentration range of 0.7 to $3.75 \mathrm{mg} / \mathrm{mL}$ (Figure 1c). Nitric oxide was generated by the decomposition of sodium nitroprusside and measured on the basis of Griess reaction [31]. The nitric oxide scavenging activity of ethyl acetate and ethanol extracts increased from $4.50 \% \pm 0.59 \%$ and $1.15 \% \pm 0.01 \%$, respectively (at $20.83 \mu \mathrm{g} / \mathrm{mL}$ ) to $84.71 \% \pm 0.34 \%$ and $62.25 \% \pm 0.63 \%$, respectively (at $166.66 \mu \mathrm{g} / \mathrm{mL}$ ). Within the same concentration range, the scavenging activity of L-ascorbic acid increased from $38.01 \% \pm 0.46 \%$ to $71.62 \% \pm 0.40 \%$. At $166.66 \mu \mathrm{g} / \mathrm{mL}$, chloroform and aqueous extracts showed weak scavenging activity on nitric oxide $(8.37 \% \pm 0.24 \%$ and $5.96 \% \pm 0.27 \%$, respectively) (Figure 1d). Among $V$. kotschyana extracts, ethyl acetate extract exhibited the strongest scavenging effects against superoxide, hydroxyl and nitric oxide radicals $\left(\mathrm{EC}_{50}=370.42 \pm 0.67 \mu \mathrm{g} / \mathrm{mL}, 0.88 \pm 0.00 \mathrm{mg} / \mathrm{mL}\right.$ and $55.50 \pm 0.27 \mu \mathrm{g} / \mathrm{mL}$, respectively). It is worthy to note its excellent nitric oxide scavenging capacity in comparison to that of the positive control, L-ascorbic acid $\left(\mathrm{EC}_{50}=46.00 \pm 0.24 \mu \mathrm{g} / \mathrm{mL}\right.$ ) (Table 1). Because of the different experimental protocols for evaluating superoxide and hydroxyl radicals scavenging effects, in many cases, a comparison of our results with other studies is not possible. Ethyl acetate extract seems to be a good scavenger of superoxide $\left(\mathrm{EC}_{50}=370.42 \pm 0.67 \mu \mathrm{g} / \mathrm{mL}\right)$ and hydroxyl radicals $\left(\mathrm{EC}_{50}=0.88 \pm 0.00\right.$ $\mathrm{mg} / \mathrm{mL}$ ) as other plant extracts tested in similar experimental conditions showed $\mathrm{EC}_{50}$ values between 0.10-2.77 $\mathrm{mg} / \mathrm{mL}$ and $0.47-1.07 \mathrm{mg} / \mathrm{mL}$, respectively [27,32-34]. Literature reports even lower activities for an extract and fractions from Tuber indicum $\left(\mathrm{EC}_{50}=3.31-25.6 \mathrm{mg} / \mathrm{mL}\right)$ in a slightly modified hydroxyl radical scavenging assay [35]. A comparison with literature data confirmed the high nitric oxide scavenging capacity of ethyl acetate extract. At $200 \mu \mathrm{g} / \mathrm{mL}$, a phenolic extract of Pinus massoniana bark exhibited $68.9 \%$ scavenging activity [36] while ethyl acetate extract showed a higher 
activity $(84.71 \%)$ in a lower concentration $(166.66 \mu \mathrm{g} / \mathrm{mL})$. In the same experimental conditions, extracts of Pinus brutia bark $\left(\mathrm{EC}_{50}=160.23-219.26 \mu \mathrm{g} / \mathrm{mL}\right)$ were less active than ethyl acetate extract $\left(\mathrm{EC}_{50}=55.50 \pm 0.27 \mu \mathrm{g} / \mathrm{mL}\right)[32]$.

\subsection{Lipid Peroxidation Inhibitory Activity}

In this assay [37], ethyl acetate extract reduced the iron-ascorbate induced lipid peroxidation of linoleic acid. At $1.3 \mathrm{mg} / \mathrm{mL}$, the lipid peroxidation inhibitory effects of $V$. kotschyana extracts decreased as follows: ethyl acetate extract $(75.66 \% \pm 0.36 \%)>$ chloroform extract $(54.52 \% \pm 0.96 \%)$ $>$ ethanol extract $(40.27 \% \pm 0.40 \%)>$ aqueous extract $(3.73 \% \pm 0.29 \%)$ (Figure 1e). The EC 50 values revealed that ethyl acetate extract possessed the highest lipid peroxidation inhibitory activity $\left(\mathrm{EC}_{50}=0.24 \pm 0.00 \mathrm{mg} / \mathrm{mL}\right)$. According to the $\mathrm{EC}_{50}$ values, the lipid peroxidation inhibitory effect of ethyl acetate extract was less pronounced than that of DL- $\alpha$-tocopherol acetate $\left(\mathrm{EC}_{50}=17.4 \pm 0.0 \mu \mathrm{g} / \mathrm{mL}\right)$ (Table 1) and other plant extracts that were tested using similar experimental protocols. Extracts of the roots of Astragalus membranaceus, Morus alba, Polygonatum odoratum and leaves of Houttuynia cordata and Saururus chinensis inhibited linoleic acid lipid peroxidation with EC50 values ranging from 6.2 to $15.3 \mu \mathrm{g} / \mathrm{mL}$ [37]. At $100 \mu \mathrm{g} / \mathrm{mL}$, extracts from the aerial parts of Galeopsis speciosa, Lamium purpureum, Lamium album, Leonurus cardiaca, Stachys officinalis and Marrubium vulgare reduced lipid peroxidation by $64.5 \%-78.7 \%$ [38]; for comparison, at the same concentration, ethyl acetate extract exhibited $27.72 \%$ activity.

\subsection{Ferrous Ion Chelating Activity}

In the ferrous ion chelating assay $[39,40]$, the chloroform extract proved to be the most active. At $5.3 \mathrm{mg} / \mathrm{mL}$, its ferrous ion chelating ability reached $63.83 \% \pm 0.87 \%$. At the same concentration, the ethanol, aqueous and ethyl acetate extracts exhibited only $43.31 \% \pm 0.52 \%, 26.52 \% \pm 0.60 \%$ and $9.81 \% \pm 0.32 \%$ chelating activity, respectively (Figure 1f). According to the EC 50 values, the chelating ability of chloroform extract was lower than that of EDTA $(3.33 \pm 0.03 \mathrm{mg} / \mathrm{mL} v s .6 .16 \pm 0.08 \mu \mathrm{g} / \mathrm{mL})$ (Table 1). Tested under the same experimental conditions, extracts of Acacia confusa bark $\left(\mathrm{EC}_{50}=253-2185.6 \mu \mathrm{g} / \mathrm{mL}\right)$ and Pinus cembra needles $\left(\mathrm{EC}_{50}=1755 \mu \mathrm{g} / \mathrm{mL}\right)$ showed stronger chelating effects than chloroform extract $[40,41]$.

\subsection{Antioxidant Activity in MCF-12F Cells}

Ethyl acetate and ethanol extracts showed the highest activity in free radical scavenging and lipid peroxidation inhibition assays. Therefore, these extracts were assessed for their ability to reduce dichlorodihydrofluorescein diacetate (DCFH-DA) oxidation in MCF-12F cells exposed to exogenous hydrogen peroxide [42]. At $150 \mu \mathrm{g} / \mathrm{mL}$, the ethyl acetate extract decreased DCFH-DA oxidation by $51.56 \% \pm 1.17 \%$, while the ethanol extract reduced it only by $34.51 \% \pm 0.20 \%$ (Figure $1 \mathrm{~g}$ ). Ethyl acetate extract $\left(\mathrm{EC}_{50}=144.46 \pm 2.57 \mu \mathrm{g} / \mathrm{mL}\right)$ was more active than ethanol extract $\left(\mathrm{EC}_{50}>150 \mu \mathrm{g} / \mathrm{mL}\right) \mathrm{but}$ less active than sodium pyruvate, the positive control $\left(\mathrm{EC}_{50}=78.43 \pm 3.03 \mu \mathrm{g} / \mathrm{mL}\right.$ ) (Table 1). 


\subsection{Phytochemical Screening}

The phytochemical study revealed the presence of steroidal compounds in all extracts. Phenols (tannins), flavonoids and saponins were detected in ethyl acetate and ethanol extracts. Additionaly, free sugars were identified in the ethanol extract. Aminoacids/proteins, polysaccharides and saponins were found to be present in aqueous extract $[43,44]$.

\subsection{FT-IR Spectroscopic Analysis}

$V$. kotschyana extracts were analysed by FT-IR spectroscopy. Chloroform extract showed strong absorption bands belonging to the stretching vibration of $\mathrm{O}-\mathrm{H}\left(3649-3336 \mathrm{~cm}^{-1}\right)$ and saturated hydrocarbon groups $\left(2921 \mathrm{~cm}^{-1}, 2852 \mathrm{~cm}^{-1}\right)$. The bands at $1159 \mathrm{~cm}^{-1}, 1074 \mathrm{~cm}^{-1}$ and $1029 \mathrm{~cm}^{-1}$ belong to the stretching vibration of $\mathrm{C}-\mathrm{O}$ and bending vibration of $\mathrm{C}-\mathrm{O}-\mathrm{H}$ groups. Other bands could be assigned to the stretching vibration of $\mathrm{C}=\mathrm{O}$ groups and aliphatic $\mathrm{CC}$ double bonds $\left(1716-1647 \mathrm{~cm}^{-1}\right)$ and bending vibration of methyl/methylene groups $\left(1456-1363 \mathrm{~cm}^{-1}\right.$ ) (Figure 2a). These spectral data indicate that long-chain alkyl (strong bands around $2920 \mathrm{~cm}^{-1}$ and $2850 \mathrm{~cm}^{-1}$ ) and steroidal compounds (bands at 3650-3590 $\mathrm{cm}^{-1}$ for free $\mathrm{O}-\mathrm{H}, 2960-2850 \mathrm{~cm}^{-1}$ for C-H stretching, $1485-1445 \mathrm{~cm}^{-1}$ for $\mathrm{CH}_{2}$ bending) are present in chloroform extract $[45,46]$. Absorption bands which could be assigned to steroidal compounds were present in all extracts.

In ethyl acetate extract, there were also present bands corresponding to the stretching vibration of O-H (3649-3336 cm $\left.\mathrm{cm}^{-1}\right)$ and saturated hydrocarbon groups $\left(2927 \mathrm{~cm}^{-1}, 2871 \mathrm{~cm}^{-1}\right)$, stretching vibration of C-O and bending vibration of C-O-H groups $\left(1157-1018 \mathrm{~cm}^{-1}\right)$, stretching vibration of $\mathrm{C}=\mathrm{O}$ groups and aliphatic $\mathrm{CC}$ double bonds $\left(1716 \mathrm{~cm}^{-1}, 1699 \mathrm{~cm}^{-1}, 1635 \mathrm{~cm}^{-1}\right)$. The bending vibration of methyl/methylene groups appeared at $1456-1363 \mathrm{~cm}^{-1}$. In addition, bands corresponding to skeletal stretching vibration of the aromatic rings and $=\mathrm{C}-\mathrm{O}-\mathrm{C}$ group of flavonoids $\left(1602 \mathrm{~cm}^{-1}, 1508 \mathrm{~cm}^{-1}\right.$, $1456 \mathrm{~cm}^{-1}, 1269 \mathrm{~cm}^{-1}, 1261 \mathrm{~cm}^{-1}$ ) were visible [47] (Figure 2b). Weaker absorption bands for phenolic compounds were also present in chloroform, ethanol and aqueous extracts $\left(1508 \mathrm{~cm}^{-1}, 1456 \mathrm{~cm}^{-1}\right.$, $1259 \mathrm{~cm}^{-1}$ ). These spectral data are in agreement with the quantitative study that showed the highest phenolic content in ethyl acetate extract followed by ethanol, chloroform and aqueous extracts (Table 2).

Table 2. Phenolic content of Vernonia kotschyana root extracts.

\begin{tabular}{cc}
\cline { 2 - 2 } Extract & $\begin{array}{c}\text { Total Phenolic Content } \\
(\mathbf{g ~ G A E} / \mathbf{1 0 0} \text { g) }\end{array}$ \\
\hline V-C & $1.08 \pm 0.03^{\mathrm{a}, \mathrm{b}, \mathrm{c}}$ \\
V-EA & $14.89 \pm 0.02^{\mathrm{b}, \mathrm{c}, \mathrm{d}}$ \\
V-E & $5.99 \pm 0.07^{\mathrm{c}, \mathrm{d}, \mathrm{a}}$ \\
Notes: ${ }^{\mathrm{a}} P<0.001$ vs. V-EA, ${ }^{\mathrm{b}} P<0.001$ vs. V-E, ${ }^{\mathrm{c}} P<0.001$ vs. V-A, ${ }^{\mathrm{d}}{ }^{\mathrm{d}, \mathrm{a}, \mathrm{b}}$ \\
\cline { 2 - 2 }
\end{tabular}

The spectra of ethanol and aqueous extracts were rather similar showing strong absorption bands attributed to the stretching vibrations of O-H (3649-3292 $\mathrm{cm}^{-1}$ and 3649-3245 $\mathrm{cm}^{-1}$, respectively) and saturated hydrocarbon groups (2929 $\mathrm{cm}^{-1}$ and $2927 \mathrm{~cm}^{-1}$, respectively), stretching vibration of C-O and bending vibration of C-O-H groups (1132-993 $\mathrm{cm}^{-1}$ and $1218-987 \mathrm{~cm}^{-1}$, respectively), stretching 
vibration of $\mathrm{C}=\mathrm{O}$ groups and aliphatic $\mathrm{CC}$ double bonds $\left(1716-1635 \mathrm{~cm}^{-1}\right)$. Bands corresponding to the bending vibration of methyl/methylene groups appeared in both spectra at $1456-1338 \mathrm{~cm}^{-1}$ (Figure $2 \mathrm{c}, \mathrm{d}$ ). In ethanol and aqueous extracts, the bands corresponding to the stretching vibration of C-O and bending vibration of C-O-H groups (1132-993 $\mathrm{cm}^{-1}$ and $1218-987 \mathrm{~cm}^{-1}$, respectively) were stronger as compared to chloroform and ethyl acetate extracts $\left(1159-1029 \mathrm{~cm}^{-1}\right.$ and $1157-1018 \mathrm{~cm}^{-1}$, respectively) indicating high amounts of carbohydrates (mono-, oligosaccharides in ethanol extract and polysaccharides in aqueous extract) [48]. In case of aqueous extract, bands at $3400-3200 \mathrm{~cm}^{-1}$, $1700-1600 \mathrm{~cm}^{-1}$ and $1575-1480 \mathrm{~cm}^{-1}$ could also be assigned to proteins/aminoacids (NH stretching, $\mathrm{C}=\mathrm{O}$ stretching and in-plane $\mathrm{NH}$ bending/CN stretching vibrations, respectively) [49,50] (Figure 2d).

These spectral data are consistent with previous studies reporting that $V$. kotschyana roots contain steroidal glycosides of stigmastane and androstane type (the former are known as vernoniosides) and carbohydrates (pectic polysaccharides, inulin type fructans) [18,19,51]. A FT-IR analysis of $V$. cinerea reported the presence of aminoacids, alkenes, ethers, organic halogen compounds and carbohydrates in the whole plant [52].

Figure 2. (a) FT-IR spectra of chloroform extract. (b) FT-IR spectra of ethyl acetate extract. (c) FT-IR spectra of ethanol extract. (d) FT-IR spectra of aqueous extract.

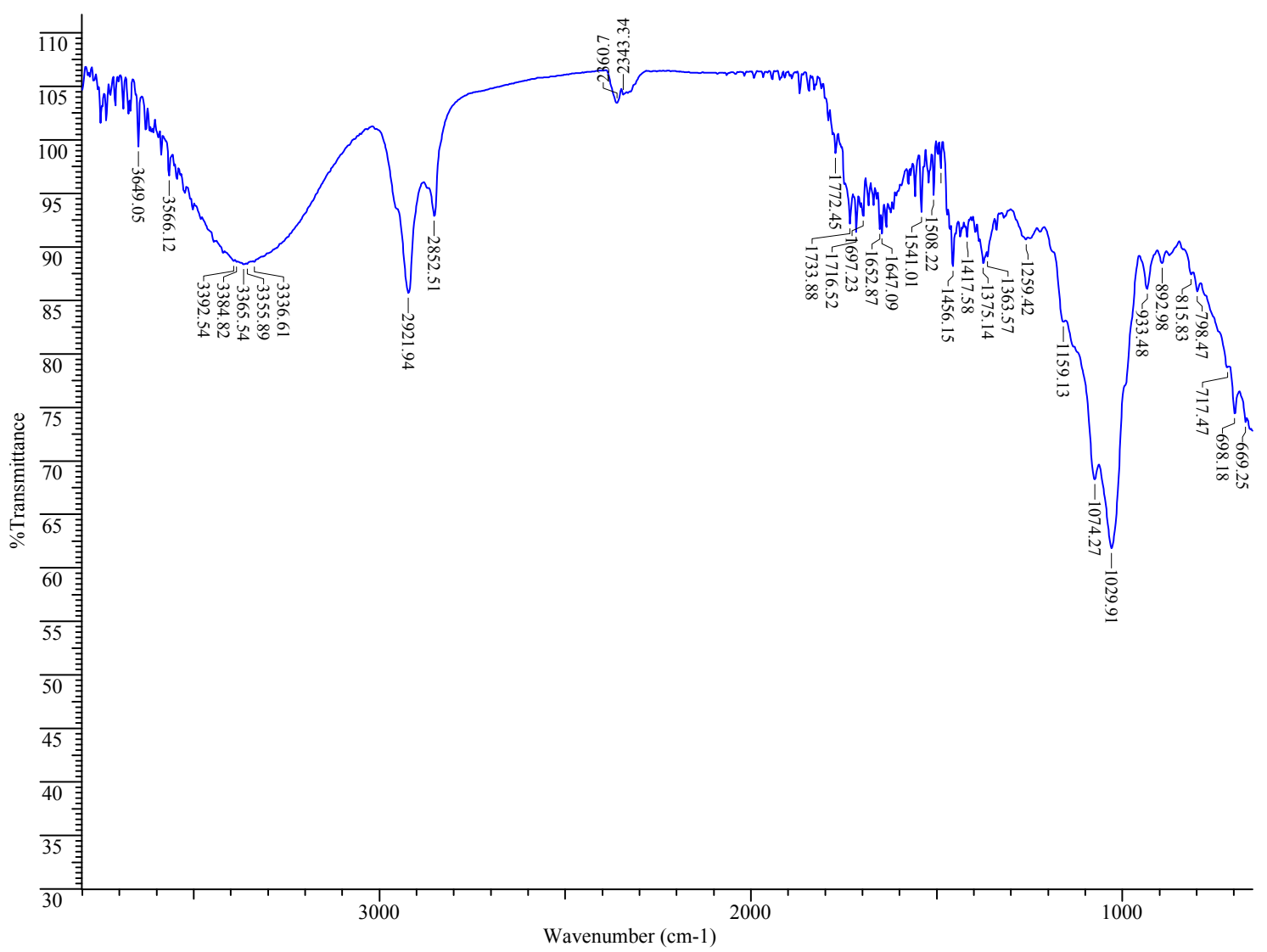

(a) 
Figure 2. Cont.

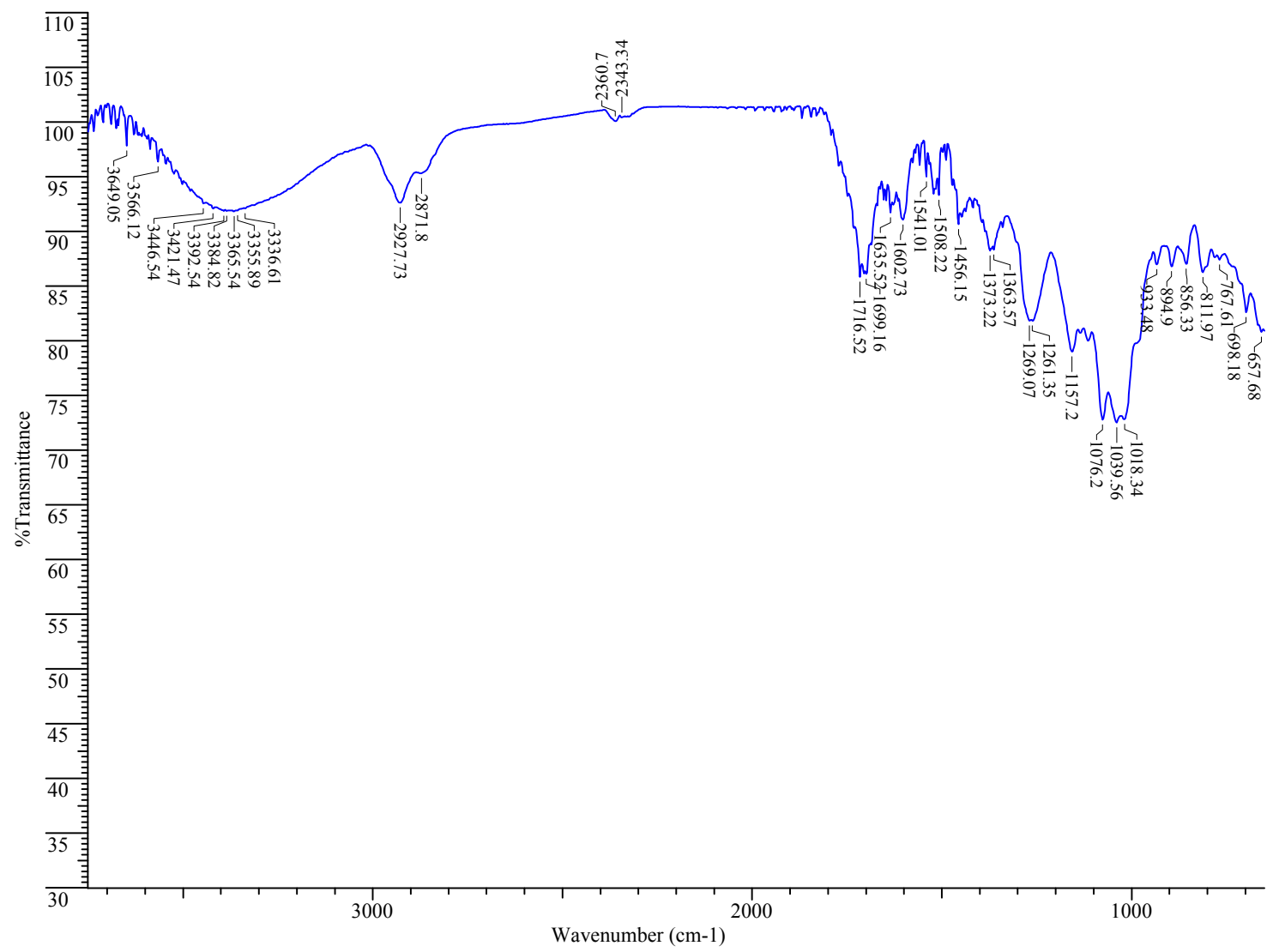

(b)

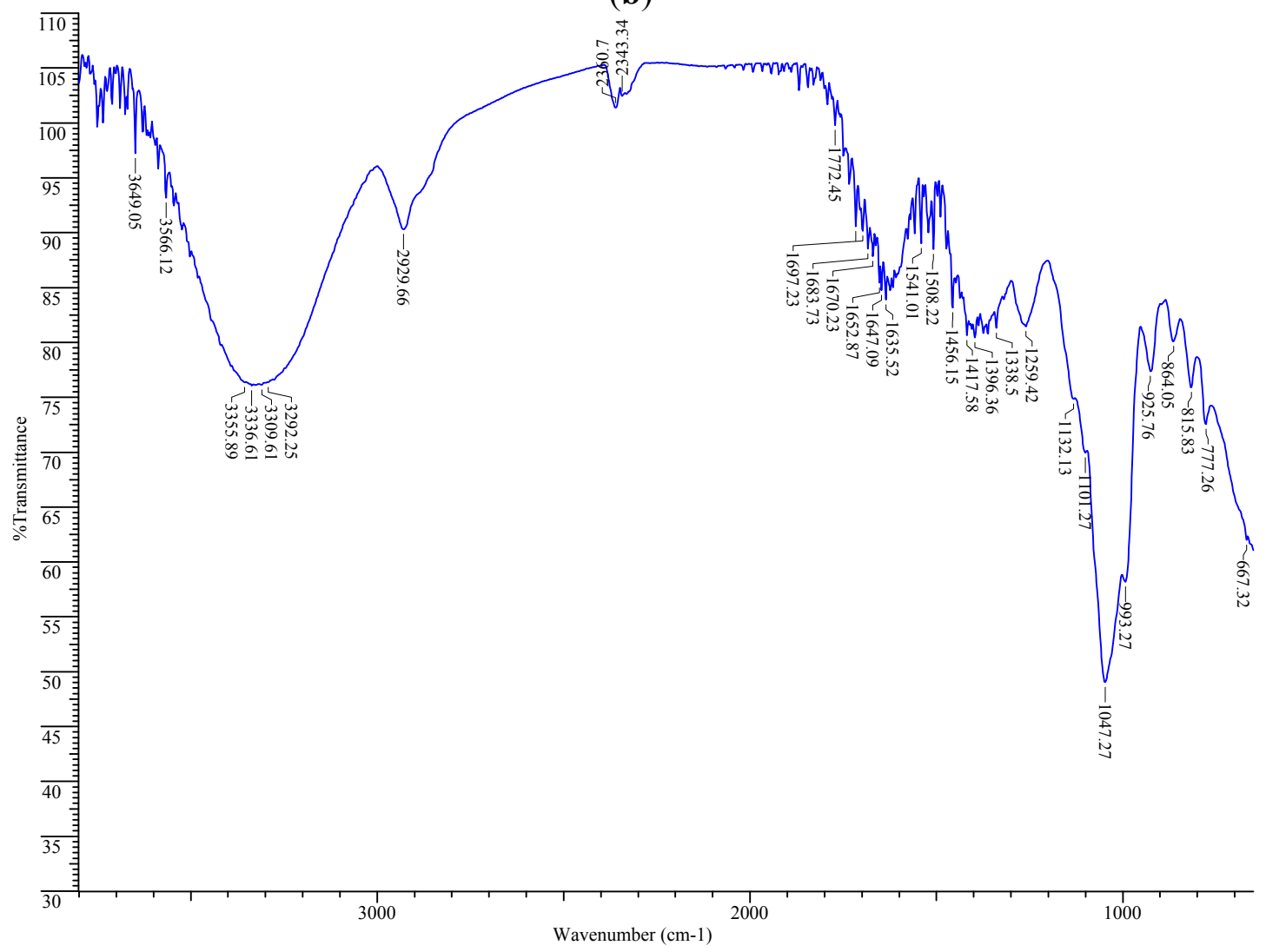

(c) 
Figure 2. Cont.

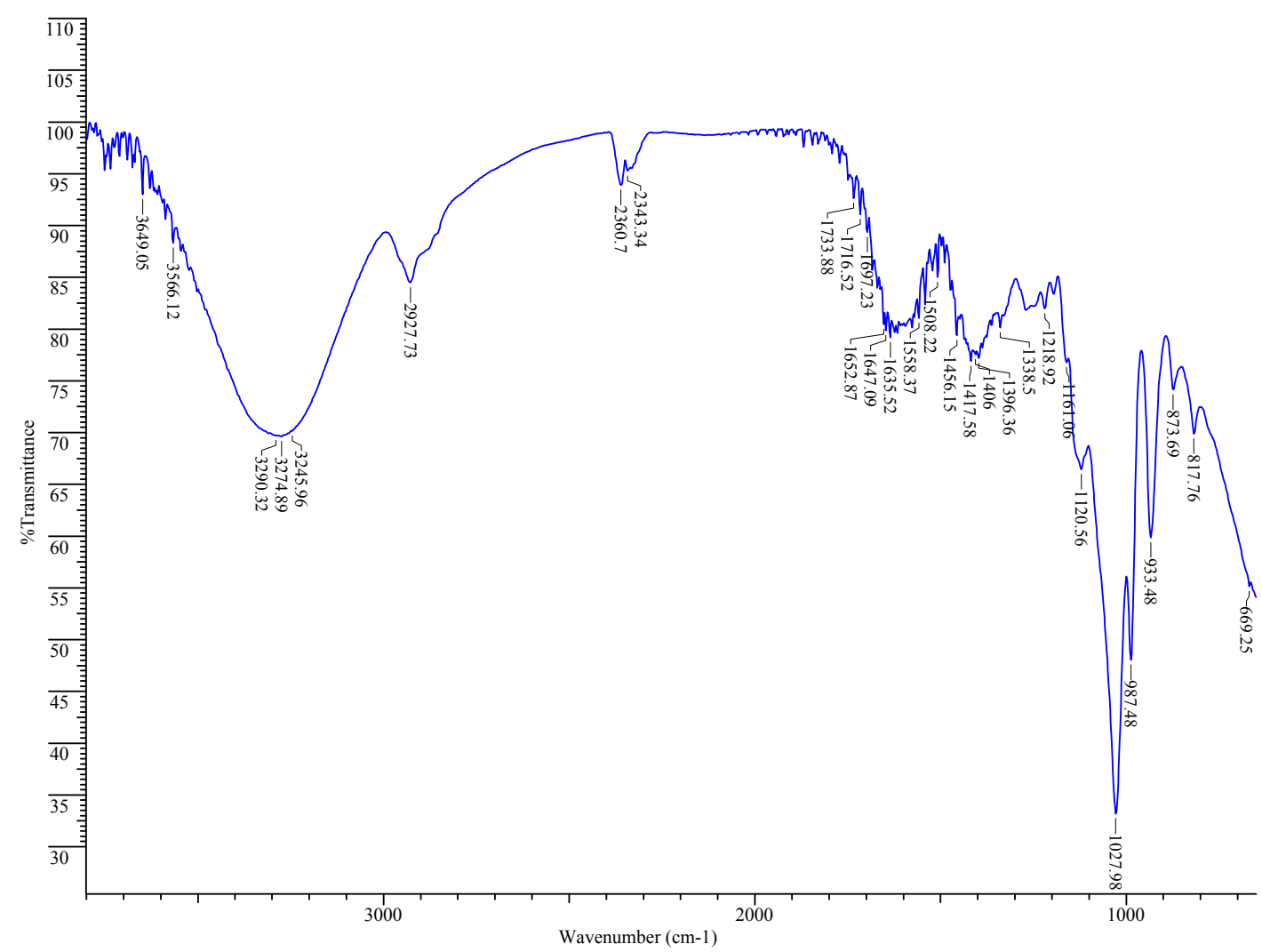

(d)

\subsection{Total Phenolic Content}

Ethyl acetate extract had the highest total phenolic content $(14.89 \% \pm 0.02 \%)$, followed by ethanol extract $(5.99 \% \pm 0.07 \%)$. The lowest amounts of polyphenols were detected in chloroform and aqueous extracts $(1.08 \% \pm 0.03 \%$ and $0.78 \% \pm 0.01 \%$, respectively) (Table 2$)$.

There are reports on phenolic contents in extracts obtained from other Vernonia species: $0.147 \%$ in the methanol extract of $V$. cinerea whole plant, $0.19 \%-23.11 \%$ in the ethanol extract of $V$. condensata leaves and its fractions, $0.35 \%$ in the aqueous extract of $V$. amygdalina leaves [25,53,54]. In light of these literature data, ethyl acetate extract of $V$. kotschyana roots contains significant amounts of polyphenols.

Among all extracts, the ethyl acetate extract exhibited the most promising antioxidant effects. It was the most active in free radical scavenging and lipid peroxidation inhibition assays but it showed a very weak activity in ferrous ion chelating assay. Free radical scavenging involves either hydrogen donation or electron transfer [55]. Ferrous ion chelation is another important antioxidant mechanism. Ferrous ions have pro-oxidant effects; they promote the generation of the highly reactive hydroxyl radical via Fenton reaction [56]. The results of this study clearly show that the antioxidant activity of the ethyl acetate extract is mainly based on its reducing capacity (hydrogen donation/electron transfer) without involving chelation of ferrous ions. The results of the chemical studies corroborated with those of the antioxidant assays suggest that polyphenols are mainly responsible for the antioxidant effects of ethyl acetate extract; other compounds than phenolics confer ferrous ion chelating capacity to chloroform extract. However, antiulcer activity of many plant extracts has been attributed to their antioxidant constituents, especially polyphenols. Gallic acid is mainly responsible for the protective activity of the 
aqueous extract of Zingiber officinale rhizome against oxidative stress-induced gastric mucosal damage [10]. Phytochemical studies revealed high contents of total phenolics and flavonoids $(159.76 \pm 0.32 \mathrm{mg} / \mathrm{g}$ and $79.51 \pm 0.57 \mathrm{mg} / \mathrm{g}$, respectively) besides polysaccharides $(506.7 \pm 5.2 \mathrm{mg} / \mathrm{g})$ in Opuntia ficus indica $f$. inermis flowers extract; the extract exhibited remarkable in vivo antiulcerogenic effects [13]. Anthocyanins are mainly responsible for the gastroprotective activity of strawberry extracts. They have high ROS scavenging effects; in addition, they enhance the biosynthesis of mucopolysaccharides and consequently the protective activity of the mucus layer. Pretreatment with cyanidin-3-glucoside, a very common anthocyanoside, significantly reversed ethanol-induced oxidative stress in gastric mucosa (increased lipid peroxidation, depletion of glutathione level and activities of antioxidant enzymes such as superoxide dismutase, catalase, glutathione peroxidase) [14]. Gastroprotective effects of Curcuma longa and Mentha piperita aqueous extracts were also attributed to polyphenols, mainly flavonoids [15]. Besides their significant ROS scavenging effects, flavonoids increase prostaglandin secretion and decrease histamine secretion from mast cells [14].

No matter the causative agent (Helicobacter pylori, alcohol, stress, NSAIDS), gastric ulceration is characterized by an increase in oxidative stress. The ethyl acetate extract showed the most potent antioxidant effects in in vitro studies, making it a good candidate for in vivo evaluation of a possible antiulcer activity in relation to its antioxidant potential. In addition, other gastroprotective mechanisms such as antisecretory and cytoprotective effects should be investigated as polyphenols have been reported to exhibit such effects in the gastrointestinal tract [57,58].

It is worthy to note that superoxide, hydroxyl, nitric oxide radicals, hydrogen peroxide and lipid peroxidation play a critical role in many other oxidative-stress related pathological conditions and diseases. Superoxide anion radical and other ROS species derived from it (hydrogen peroxide, hydroxyl radical) are responsible for myocardial tissue damage in ischemia/reperfusion injury; they are also involved in the pathogenesis of hypertension, chronic obstructive pulmonary disease, diabetic complications (coronary and peripheral artery diseases, diabetic retinopathy, nephropathy and neuropathy) [59,60]. Hydroxyl radical-induced DNA damage is involved in the initiation, promotion and progression of carcinogenesis [61]. High levels of nitric oxide produced by iNOS have been detected in inflammatory disorders of the joints, lungs and gut, atherosclerosis, cancer and diabetes [62]. Lipid peroxidation is crucial in the development of atherosclerosis and several neurodegenerative diseases (amyotrophic lateral sclerosis, Alzheimer's and Parkinson's diseases) [63,64]. All these facts suggest a possible use of the ethyl acetate extract as ingredient in dietary supplements for pathological conditions and diseases associated with oxidative stress. In vivo studies on antiulcer and antioxidant potential of ethyl acetate extract are in progress.

\section{Experimental Section}

\subsection{Chemicals}

Tris(hydroxymethyl)aminomethane (Tris), hydrochloric acid, ferrous chloride, sodium chloride, sodium nitroprusside were purchased from Merck (Darmstadt, Germany). ABTS diammonium salt, ethylenediaminetetraacetic acid (EDTA), 3-(2-pyridyl)-5,6-diphenyl-1,2,4-triazine-4',4"-disulfonic acid monosodium salt (ferrozine), disodium phosphate dodecahydrate, monopotassium phosphate, 
glutathione, pyrogallol, Folin-Ciocalteu's phenol reagent were supplied by Fluka (Steinheim, Germany). DL- $\alpha$-Tocopherol acetate was from Sigma-Aldrich (Buchs, Switzerland). Sodium carbonate, iron (II) sulfate heptahydrate, hydrogen peroxide, L-ascorbic acid, linoleic acid, thiobarbituric acid, $N$-(1-naphthyl)ethylenediamine dihydrochloride, sodium salicylate, sulfanilamide, acetic acid were obtained from Sigma-Aldrich Chemie GmbH (Steinheim, Germany). Gallic acid monohydrate, trichloroacetic acid and potassium persulfate were purchased from Riedel-de Haën (Seelze, Germany). Dulbecco's Modified Eagle's Medium/Ham's Nutrient Mixture F-12 (DMEM/F-12), horse serum, antibiotic-antimycotic and trypsin were purchased from Gibco/Invitrogen (Carlsbad, CA, USA). Insulin, hydrocortisone, cholera toxin, epidermal growth factor (EGF), DCFH-DA, sodium pyruvate were purchased from Sigma (St. Louis, MO, USA).

\subsection{Cell Culture}

MCF-12F cell line (normal human mammary epithelial cell line) was obtained from the American Type Culture Collection (ATCC, Manassas, VA, USA). MCF-12F cells were routinely cultured in DMEM/F-12 supplemented with $5 \%$ horse serum, $1 \%$ antibiotic-antimycotic, $10 \mu \mathrm{g} / \mathrm{mL}$ insulin, $500 \mathrm{ng} / \mathrm{mL}$ hydrocortisone, $100 \mathrm{ng} / \mathrm{mL}$ cholera toxin and $20 \mathrm{ng} / \mathrm{mL}$ EGF. Cells were grown in a humidified atmosphere with $5 \% \mathrm{CO}_{2}$ at $37{ }^{\circ} \mathrm{C}$.

\subsection{Plant Material}

The roots of Vernonia kotschyana were kindly supplied by the Department of Traditional Medicine, Bamako, Mali. The identity of plant material was authenticated by Prof. Drissa Diallo, Director of the Department of Traditional Medicine in Bamako. A voucher specimen (VKR2011) is deposited in the Laboratory of Pharmacognosy, Faculty of Pharmacy, Grigore T. Popa University of Medicine and Pharmacy — Iasi, Romania.

\subsection{Preparation of Extracts}

Dried and powdered roots $(200 \mathrm{~g})$ were extracted successively with chloroform $(3 \times 1000 \mathrm{~mL}$, each time for $4 \mathrm{~h}$ ) under reflux in a water bath at $50{ }^{\circ} \mathrm{C}$. The vegetal residue was extracted sequentially with ethyl acetate, ethanol and water as described above. The chloroform, ethyl acetate and ethanol extracts were evaporated to dryness under reduced pressure at $40{ }^{\circ} \mathrm{C}$ while the water extract was lyophilized. All extracts were stored at $4{ }^{\circ} \mathrm{C}$ until use.

\subsection{ABTS Radical Cation Scavenging Assay}

The assay was performed as described by Re et al., [23]. ABTS radical cation, generated by incubation of ABTS $(7 \mathrm{mM})$ with potassium persulfate $(2.45 \mathrm{mM})$ for $12-16 \mathrm{~h}$ in dark, was further diluted with ethanol to an absorbance of $0.70 \pm 0.02$ at $734 \mathrm{~nm}$. In order to evaluate the scavenging activity, extracts $(0.15-10 \mathrm{mg} / \mathrm{mL})$ were mixed with ABTS radical cation solution in a total volume of $2 \mathrm{~mL}$. The decay in absorbance at $734 \mathrm{~nm}$ was measured after $6 \mathrm{~min}$ of reaction at $30{ }^{\circ} \mathrm{C}$. Glutathione was used as positive control. Percent ABTS radical cation scavenging activity was calculated using the 
following formula: $100 \times\left(\mathrm{A}_{\text {control }}-\mathrm{A}_{\text {sample }} / \mathrm{A}_{\text {control }}\right)$ where $\mathrm{A}_{\text {control }}$ is the absorbance of the control and Asample is the absorbance in the presence of extracts/glutathione.

\subsection{Superoxide Anion Radical Scavenging Assay}

A slightly modified method of Marklund and Marklund was used to evaluate superoxide scavenging effects [28,29]. The reaction mixture $(3.1 \mathrm{~mL})$ contained different concentrations of extracts (7.5-20 mg/mL), $1 \mathrm{mM}$ EDTA in $50 \mathrm{mM}$ Tris-HCl buffer at $\mathrm{pH} 8.0$ and $6 \mathrm{mM}$ pyrogallol. The increase in absorbance at $325 \mathrm{~nm}$ was measured every $30 \mathrm{~s}$ for $4 \mathrm{~min}$. Glutathione was the positive control. Percent superoxide anion radical scavenging activity was calculated by the formula: $100 \times$ (slope $_{\text {control }}-$ slope $_{\text {sample/slope }}$ control$)$ where slope control $_{\text {and slope }}$ sample are the slopes of the plots of absorbance $v s$. time for control and samples, respectively [28].

\subsection{Hydroxyl Radical Scavenging Assay}

The assay was performed as reported by Jeong et al. [30]. The reaction mixture, containing extracts (5-40 mg/mL), $1.5 \mathrm{mM}$ iron (II) sulfate heptahydrate, $20 \mathrm{mM}$ sodium salicylate and $6 \mathrm{mM}$ hydrogen peroxide in a total volume of $2.4 \mathrm{~mL}$, was incubated at $37^{\circ} \mathrm{C}$ for $30 \mathrm{~min}$. After cooling, the absorbance was measured at $562 \mathrm{~nm}$. L-Ascorbic acid was used as positive control. Percent hydroxyl radical scavenging activity was calculated using the formula: $100 \times\left(\mathrm{A}_{\text {control }}-\mathrm{A}_{\text {sample }} / \mathrm{A}_{\text {control}}\right)$.

\subsection{Nitric Oxide Scavenging Assay}

Nitric oxide scavenging activity was evaluated according to the method described by Tsai et al. [31]. Extracts $(0.62-5 \mathrm{mg} / \mathrm{mL})$ were mixed with $10 \mathrm{mM}$ sodium nitroprusside followed by dilution with phosphate buffered saline to give a final volume of $3 \mathrm{~mL}$. After $150 \mathrm{~min}$ incubation at $25{ }^{\circ} \mathrm{C}$, an aliquot of the reaction mixture $(0.5 \mathrm{~mL})$ was mixed with $0.33 \%$ sulfanilamide in $20 \%$ acetic acid $(1 \mathrm{~mL})$ and $0.1 \%$ naphthylethylenediamine dihydrochloride $(1 \mathrm{~mL})$. After $30 \mathrm{~min}$ the absorbance was measured at $540 \mathrm{~nm}$. L-Ascorbic acid was the positive control. Percent nitric oxide scavenging activity was calculated as $100 \times\left(\mathrm{A}_{\text {control }}-\mathrm{A}_{\text {sample }} / \mathrm{A}_{\text {control }}\right)$.

\subsection{Lipid Peroxidation Inhibition Assay}

Inhibition of lipid peroxidation was assessed by the method described by Choi et al. with minor changes [37]. In brief, the reaction mixture, containing extracts $(2.5-30 \mathrm{mg} / \mathrm{mL}), 20 \mathrm{mM}$ linoleic acid, $4 \mathrm{mM}$ iron (II) sulfate heptahydrate, $2 \mathrm{mM}$ ascorbic acid and $100 \mathrm{mM}$ Tris buffer (pH 7.5) in a total volume of $1.3 \mathrm{~mL}$, was incubated at $37{ }^{\circ} \mathrm{C}$ for $30 \mathrm{~min}$. A volume of $1 \mathrm{~mL}$ of $5.5 \%$ trichloroacetic acid and $1 \%$ thiobarbituric acid was further added followed by heating at $95{ }^{\circ} \mathrm{C}$ for $20 \mathrm{~min}$. After cooling and centrifugation, the absorbance was measured at $532 \mathrm{~nm}$. DL- $\alpha$-Tocopherol acetate was the positive control. Percent lipid peroxidation inhibition was calculated using the following formula: $100 \times\left(\mathrm{A}_{\text {control }}-\mathrm{A}_{\text {sample }}\right) /\left(\mathrm{A}_{\text {control }}-\mathrm{A}_{\text {blank }}\right)$ where $\mathrm{A}_{\text {blank }}$ is the absorbance of the mixture containing only linoleic acid and Tris buffer. 


\subsection{Ferrous Ion Chelating Assay}

The assay was carried out according to the method of Dinis et al., with minor changes [39,40]. Extracts $(2.5-40 \mathrm{mg} / \mathrm{mL})$ were mixed vigorously with $2 \mathrm{mM}$ ferrous chloride, $5 \mathrm{mM}$ ferrozine and ethanol in a total volume of $3.02 \mathrm{~mL}$. After $10 \mathrm{~min}$ incubation at room temperature, the absorbance was determined at $562 \mathrm{~nm}$. EDTA was used as positive control. Percent ferrous ion chelating activity was calculated as follows: $100 \times\left(\mathrm{A}_{\text {control }}-\mathrm{A}_{\text {sample }} / \mathrm{A}_{\text {control }}\right)$.

\subsection{Cell-Based Antioxidant Assay}

Antioxidant activity in MCF-12F cells was evaluated according to the method reported by Girard-Lalancette et al. with some modifications [42]. Hydrogen peroxide was used as intracellular oxidizing agent instead of tert-butylhydroperoxide. Briefly, MCF-12F cells were seeded in transparent 12-well plates at a final concentration of $4 \times 10^{4}$ cells/well and incubated at $37{ }^{\circ} \mathrm{C}$ in $5 \% \mathrm{CO}_{2}$ humidified atmosphere. After $24 \mathrm{~h}$, the medium was removed and the cells were further treated with 1 $\mathrm{mL}$ of DMEM/F-12 containing $100 \mu \mathrm{M}$ DCFH-DA followed by addition of $1 \mu \mathrm{L}$ of extracts or sodium pyruvate $(20-150 \mathrm{mg} / \mathrm{mL})$ and $1.1 \mu \mathrm{L}$ of $100 \mu \mathrm{M}$ hydrogen peroxide. Inside the cells, DCFH-DA is hydrolysed to DCFH by intracellular esterases; in the presence of ROS, DCFH is oxidized to highly fluorescent DCF. DCF fluorescence intensity was measured after $30 \mathrm{~min}$ incubation with hydrogen peroxide using an Infinite F200 PRO multimode reader (Tecan, Männedorf, Switzerland) (excitation wavelength $485 \mathrm{~nm}$, emission wavelength $535 \mathrm{~nm}$ ).

\subsection{Phytochemical Screening}

Identification of the main constituents was performed according to standard procedures: Liebermann's and Salkowski's tests for steroidal ring, foam test for saponins, ferric chloride test for phenols (tannins), sodium hydroxide test for flavonoids, Fehling's test for free sugars and polysaccharides (for the latter, after a previous acidic hydrolysis) and ninhydrin test for aminoacids/proteins [43,44].

\subsection{FT-IR Spectroscopic Analysis}

FT-IR spectra were recorded on ABB MB3000 FT-IR spectrometer (Québec, QC, Canada). FT-IR spectra were acquired over a range of $4000-650 \mathrm{~cm}^{-1}$ with 16 scans at a spectrum resolution of $4 \mathrm{~cm}^{-1}$. Spectra processing was carried out using the Horizon MB software.

\subsection{Quantification of Total Phenolic Content}

Total phenolic content was quantified by Folin-Ciocalteu method as previously described [65]. In brief, a reaction mixture $(4 \mathrm{~mL})$ containing extracts, Folin-Ciocalteu's phenol reagent and 20\% sodium carbonate solution was incubated for $2 \mathrm{~h}$ in dark at room temperature. Absorbance was measured at $765 \mathrm{~nm}$. The results were expressed as g of gallic acid equivalents (GAE) per $100 \mathrm{~g}$ of extract. 


\subsection{Statistical Analysis}

All experiments were performed in triplicate and the results were expressed as mean \pm standard error. The $\mathrm{EC}_{50}$ values were calculated by linear interpolation between values above and below 50\% activity. Statistical evaluation was performed using Student's $t$ test; $P<0.05$ was considered statistically significant.

\section{Conclusions}

Vernonia kotschyana roots have been used in Malian traditional medicine for the treatment of gastroduodenal ulcers and gastritis. To the best of our knowledge, this is the first report on the antioxidant activity of Vernonia kotschyana roots. Our study revealed that an ethyl acetate extract of the roots efficiently scavenged ABTS, superoxide, hydroxyl and nitric oxide radicals and inhibited lipid peroxidation. The extract also showed a high hydrogen peroxide scavenging capacity in normal cells. As superoxide, hydroxyl, nitric oxide radicals, hydrogen peroxide and lipid peroxidation are known to be involved in gastric ulceration, the ethyl acetate extract merits further investigation of its antiulcer activity. Identification of this antioxidant potential in the ethyl acetate extract may extend the use of the roots towards the prevention and treatment of other diseases characterized by an increase in oxidative stress.

\section{Acknowledgments}

A.V. acknowledges AMPOSDRU for financial support of the research in the project "Interuniversity partnership for increasing the medical doctoral research quality and interdisciplinarity through doctoral scholarships_-DocMed.net" (POSDRU/107/1.5/S/78702).

\section{Author Contributions}

A.M., C.M.G., A.C.A., V.B. designed the research protocol; A.V., A.M., C.M.G performed the cell-free antioxidant assays and analyzed the data; A.V., C.C., A.I.C. performed the cell-based antioxidant assay and analyzed the data; A.V., I.V., A.M. performed the chemical assays and analyzed the data; A.M., C.M.G., A.V., B.S.P., D.D. wrote and corrected the drafts and final version of the manuscript.

\section{Conflicts of Interest}

The authors declare no conflict of interest.

\section{References}

1. Borrelli, F.; Izzo, A.A. The plant kingdom as a source of anti-ulcer remedies. Phytother. Res. 2000, 14, 581-591.

2. Al Mofleh, I.A. Spices, herbal xenobiotics and the stomach: Friends or foes? World J. Gastroenterol. 2010, 16, 2710-2719. 
3. Sakaguchi, A.A.; Miura, S.; Takeuchi, T.; Hokari, R.; Mizumori, M.; Yoshida, H.; Higuchi, H.; Mori, M.; Kimura, H.; Suzuki, H.; et al. Increased expression of inducible nitric oxide synthase and peroxynitrite in Helicobacter pylori gastric ulcer. Free Radic. Biol. Med. 1999, 27, 781-789.

4. Parra-Cid, T.; Calvino-Fernández, M.; Gisbert, J.P. Helicobacter pylori and peptic ulcer-role of reactive oxygen species and apoptosis. In Peptic Ulcer Disease; Chai, J., Ed.; InTech: Rijeka, Croatia, 2011; pp. 165-186.

5. Suzuki, H.; Nishizawa, T.; Ysugawa, H.; Mogami, S.; Hibi, T. Role of oxidative stress in stomach disorders. J. Clin. Biochem. Nutr. 2012, 50, 35-39.

6. Choochuay, S.; Thong-Ngam, D.; Patumraj, S.; Klaikaew, N. Effects of curcumin on gastric microcirculation with nonsteroidal anti-inflammatory drugs induced gastric injury in rats. Thai J. Gastroenterol. 2010, 11, 22-27.

7. Liu, X.; Chen, Z.; Mao, N.; Xie, Y. The protective of hydrogen on stress-induced gastric ulceration. Int. Immunopharmacol. 2012, 13, 197-203.

8. Demir, S.; Yilmaz, M.; Köseoğlu, M.; Akalin, N.; Aslan, D.; Aydin, A. Role of free radicals in peptic ulcer and gastritis. Turk. J. Gastroenterol. 2003, 14, 39-43.

9. Dolatkhah, H.; Rahbani-Nobar, M.; Fattahi, E.; Ansari, M.; Mirza-Aghazadeh, A.; Eftekhari-Vash, L.; Fakhrjo, A.; Bahrami, A. Evaluation of glycemic control, gastric juice nitric oxide and oxidative stress in diabetic patients infected by Helicobacter pylori. J. Med. Genet. Genomics 2011, 3, 1-6.

10. Nanjundaiah, S.M.; Annaiah, H.N.M.; Dharmesh, S.M. Gastroprotective effect of ginger rhizome (Zingiber officinale) extract: role of gallic acid and cinnamic acid in $\mathrm{H}^{+}, \mathrm{K}^{+}$-ATPase/H. pylori inhibition and anti-oxidative mechanism. Evid. Based Complement. Altern. Med. 2011, doi:10.1093/ecam/nep060.

11. Al Batran, R.; Al-Bayaty, F.; Jamil Al-Obaidi, M.M.; Abdualkader, A.M.; Hadi, H.A.; Ali, H.M.; Abdulla, M.A. In vivo antioxidant and antiulcer activity of Parkia speciosa ethanolic leaf extract against ethanol-induced gastric ulcer in rats. PLoS One 2013, 8, e64751, doi:10.1371/journal.pone.0064751.

12. Fernandes, H.B.; Silva, F.V.; Passos, F.F.B.; Bezerra, R.D.S.; Chaves, M.H.; Oliveira, F.A.; Oliveira, R.C.M. Gastroprotective effect of the ethanolic extract of Parkia platycephala Benth. leaves against acute gastric lesion models in rodents. Biol. Res. 2010, 43, 451-457.

13. Alimi, H.; Hfaiedh, N.; Bouoni, Z.; Sakly, M.; Ben Rhouma, K. Evaluation of antioxidant and antiulcerogenic activities of Opuntia ficus indica $f$. inermis flowers extract in rats. Environ. Toxicol. Pharmacol. 2011, 32, 406-416.

14. Alvarez-Suarez, J.M.; Dekanski, D.; Ristić, S.; Radonjić, N.V.; Petronijević, N.D.; Giampieri, F.; Astolfi, P.; González-Paramás, A.M.; Santos-Buelga, C.; Tulipani, S.; et al. Strawberry polyphenols attenuate ethanol-induced gastric lesions in rats by activation of antioxidant enzymes and attenuation of MDA increase. PLoS One 2011, 6, e25878, doi:10.1371/journal.pone.0025878.

15. Sumanth, M.; Edison, D. Comparison of antiulcer activity of Curcuma longa with Mentha piperita. JIVA 2012, 10, 30-36.

16. Verma, V.K.; Singh, N.; Saxena, P.; Singh, R. Anti-ulcer and antioxidant activity of Moringa oleifera (Lam) leaves against aspirin and ethanol induced gastric ulcer in rats. Int. Res. J. Pharm. 2012, 2, 46-57. 
17. Toyang, N.J.; Verpoorte, R. A review of the medicinal potential of plants of the genus Vernonia (Asteraceae). J. Ethnopharmacol. 2013, 146, 681-723.

18. Nergard, C.S.; Diallo, D.; Michaelsen, T.E.; Malterud, K.E.; Kiyohara, H.; Matsumoto, T.; Yamada, H.; Paulsen, B.S. Isolation, partial characterisation and immunomodulating activities of polysaccharides from Vernonia kotschyana Sch. Bip. ex Walp. J. Ethnopharmacol. 2004, 91, $141-152$.

19. Austarheim, I.; Nergard, C.S.; Sanogo, R.; Diallo, D.; Paulsen, B.S. Inulin-rich fractions from Vernonia kotschyana roots have anti-ulcer activity. J. Ethnopharmacol. 2012, 144, 82-85.

20. Germano, M.P.; de Pasquale, R.; Iauk, L.; Galati, E.M.; Keita, A.; Sanogo, R. Antiulcer activity of Vernonia kotschyana Sch. Bip. Phytomedicine 1996, 2, 229-233.

21. Inngjerdingen, K.T.; Thöle, C.; Diallo, D.; Paulsen, B.S.; Hensel, A. Inhibition of Helicobacter pylori adhesion to human gastric adenocarcinoma epithelial cells by aqueous extracts and pectic polysaccharides from the roots of Cochlospermum tinctorium A. Rich. and Vernonia kotschyana Sch. Bip. ex Walp. Fitoterapia 2014, 95, 127-132.

22. Inngjerdingen, K.T.; Meskini, A.; Austarheim, I.; Ballo, M.; Inngjerdingen, M.; Michaelsen, T.E.; Diallo, D.; Paulsen, B.S. Chemical and biological characterization of polysaccharides from wild and cultivated roots of Vernonia kotschyana. J. Ethnopharmacol. 2012, 139, 350-358.

23. Re, R.; Pellegrini, N.; Proteggente, A.; Pannala, A.; Yang, M.; Rice-Evans, C. Antioxidant activity applying an improved ABTS radical cation decolorization assay. Free Radic. Biol. Med. 1999, 26, 1231-1237.

24. Daffodil, E.D.; Lincy, P.; Mohan, V.R. Study of whole plant of Vernonia cinerea Less. for in vitro antioxidant activity. Int. J. Pharm. 2014, 4, 172-178.

25. Leelaprakash, G.; Mohan Dass, S.; Sivajothi, V. Antioxidant and hepatoprotective activities of Vernonia cinerea extract against $\mathrm{CCl} 4$ induced hepatotoxicity in albino rats. Int. J. Pharm. Sci. Rev. Res. 2011, 10, 30-34.

26. Cretu, E.; Salminen, J.-P.; Karonen, M.; Miron, A.; Charalambous, C.; Constantinou, A.I.; Aprotosoaie, A.C. In vitro antioxidant activity and phenolic content of Cedrus brevifolia bark. Nat. Prod. Commun. 2014, 9, 481-482.

27. Li, X.; Wu, X.; Huang, L. Correlation between antioxidant activities and phenolic contents of radix Angelicae sinensis (Danggui). Molecules 2009, 14, 5349-5361.

28. Marklund, S.; Marklund, G. Involvement of the superoxide anion radical in the autoxidation of pyrogallol and a convenient assay for superoxide dismutase. Eur. J. Biochem. 1974, 47, 469-474.

29. Wang, Z.; Luo, D. Antioxidant activities of different fractions of polysaccharide purified from Gynostemma pentaphyllum Makino. Carbohydr. Polym. 2007, 68, 54-58.

30. Jeong, J.B.; Hong, S.C.; Jeong, H.J. 3,4-Dihydroxybenzaldehyde purified from the barley seeds (Hordeum vulgare) inhibits oxidative DNA damage and apoptosis via its antioxidant activity. Phytomedicine 2009, 16, 85-94.

31. Tsai, P.-J.; Tsai, T.-H.; Yu, C.-H.; Ho, S.-C. Evaluation of NO-supressing activity of several Mediterranean culinary spices. Food Chem. Toxicol. 2007, 45, 440-447. 
32. Cretu, E.; Miron, S.D.; Miron, A. Bioactivity screening of Pinus brutia bark extracts: Superoxide dismutase-like activity and nitric oxide scavenging effects. Rev. Med. Chir. Soc. Med. Nat. Iasi 2013, 117, 551-557.

33. Cretu, E.; Karonen, M.; Salminen, J.-P.; Mircea, C.; Trifan, A.; Charalambous, C.; Constantinou, A.I.; Miron, A. In vitro study on the antioxidant activity of a polyphenol-rich extract from Pinus brutia bark and its fractions. J. Med. Food 2013, 16, 1-8.

34. Cretu, E.; Trifan, A.; Aprotosoaie, A.C.; Miron, A. 15-Lipoxygenase inhibition, superoxide and hydroxyl radicals scavenging activities of Cedrus brevifolia bark extracts. Rev. Med. Chir. Soc. Med. Nat. Iasi 2013, 117, 250-256.

35. Guo, T.; Wei, L.; Sun, J.; Hou, C.-L.; Fan, L. Antioxidant activities of extract and fractions from Tuber indicum Cooke \& Massee. Food Chem. 2011, 127, 1634-1640.

36. Yu, L.; Zhao, M.; Wang, J.S.; Cui, C.; Yang, B.; Jiang, Y.; Zhao, Q. Antioxidant, immunomodulatory and anti-breast cancer activities of phenolic extract from pine (Pinus massoniana Lamb) bark. Innov. Food Sci. Emerg. Technol. 2008, 9, 122-128.

37. Choi, C.W.; Kim, S.C.; Hwang, S.S.; Choi, B.K.; Ahn, H.J.; Lee, M.Y.; Park, S.H.; Kim, S.K. Antioxidant activity and free radical scavenging capacity between Korean medicinal plants and flavonoids by assay-guided comparison. Plant Sci. 2002, 163, 1161-1168.

38. Matkowski, A.; Piotrowska, M. Antioxidant and free radical scavenging activities of some medicinal plants from the Lamiaceae. Fitoterapia 2006, 77, 346-353.

39. Dinis, T.C.P.; Madeira, V.M.C.; Almeida, L.M. Action of phenolic derivatives (acetaminophen, salicylate and 5-aminosalicylate) as inhibitors of membrane lipid peroxidation and peroxyl radical scavengers. Arch. Biochem. Biophys. 1994, 315, 161-169.

40. Tung, Y.T.; Wu, J.H.; Huang, C.Y.; Kuo, Y.H.; Chang, S.T. Antioxidant activities and phytochemical characteristics of extracts from Acacia confusa bark. Bioresour. Technol. 2009, 100, 509-514.

41. Apetrei, C.L.; Tuchilus, C.; Aprotosoaie, A.C.; Oprea, A.; Malterud, K.E.; Miron, A. Chemical, antioxidant and antimicrobial investigations of Pinus cembra L. bark and needles. Molecules 2011, 16, 7773-7788.

42. Girard-Lalancette, K.; Pichette, A.; Legault, J. Sensitive cell-based assay using DCFH oxidation for the determination of pro- and antioxidant properties of compounds and mixtures: Analysis of fruit and vegetable juices. Food Chem. 2009, 115, 720-726.

43. Trease, G.E.; Evans, W.C. Pharmacognosy, 13th ed.; Bailliere Tindall: London, UK, 1989; pp. 176-180.

44. Yadav, R.N.S.; Agarwala, M. Phytochemical analysis of some medicinal plants. J. Phytol. 2011, $3,10-14$.

45. Wu, Y.-W.; Sun, S.-Q.; Zhao, J.; Li, Y.; Zhou, Q. Rapid discrimination of extracts of Chinese propolis and poplar buds by FT-IR and 2D IR correlation spectroscopy. J. Mol. Struct. 2008, 883-884, 48-54.

46. Velásquez Ballesteros, O.J.; Murillo Perea, E.; Jairo Méndez, J.; Murillo Arango, W.; Moreňa, D.A. Quantification, chemical and biological characterization of the saponosides material from Sida cordifolia L. (escobilla). Rev. Cubana Plant. Med. 2013, 18, 298-314. 
47. Adib, A.M.; Jamaludin, F.; Kiong, L.S.; Hashim, N.; Abdullah, Z. Two-dimensional correlation infrared spectroscopy applied to analyzing and identifying the extracts of Baeckea frutescens medicinal materials. J. Pharm. Biomed. Anal. 2014, 96, 104-110.

48. Grube, M.; Bekers, M.; Upite, D.; Kaminska, E. Infrared spectra of some fructans. Spectroscopy 2002, 16, 289-296.

49. Kong, J.; Yu, S. Fourier transform infrared spectroscopic analysis of protein secondary structures. Acta Biochem. Biophys. Sin. 2007, 39, 549-559.

50. Gokulakumar, B.; Narayanaswamy, R. Fourier transform-infrared spectra (FT-IR) analysis of root rot disease in sesame (Sesamum indicum). Romanian J. Biophys. 2008, 18, 217-223.

51. Sanogo, R.; Germano, M.P.; de Tommasi, N.; Pizza, C.; Aquino, R. Vernoniosides and an androstane glycoside from Vernonia kotschyana. Phytochemistry 1998, 47, 73-78.

52. Daffodil, E.D.; Lincy, P.; Mohan, V.R. Pharmacochemical characterization, FT-IR and antibacterial activity of Vernonia cinerea Less. Res. J. Pharm. Biol. Chem. Sci. 2014, 5, 239-249.

53. Da Silva, J.B.; Temponi, V.S.; Gasparetto, C.M.; Fabri, R.L.; Aragão, D.M.O.; Pinto, N.C.; Ribeiro, A.; Scio, E.; Del-Vechio-Vieira, G.; de Sousa, O.V.; et al. Vernonia condensata Baker (Asteraceae): A promising source of antioxidants. Oxidative Med. Cell. Longev. 2013, doi:10.1155/2013/698018.

54. Nwaoguikpe, R.N. The effect of extract of bitter leaf (Vernonia amygdalina) on blood glucose levels of diabetic rats. Int. J. Biol. Chem. Sci. 2010, 4, 721-729.

55. Villaño, D.; Fernández-Pachón, M.S.; Moyá, M.L.; Troncoso, A.M.; García-Parrilla, M.C. Radical scavenging ability of polyphenolic compounds towards DPPH free radical. Talanta 2007, $71,230-235$.

56. Valko, M.; Rhodes, C.J.; Moncol, J.; Izakovic, M.; Mazur, M. Free radicals, metals and antioxidants in oxidative-stress induced cancer. Chem. Biol. Interact. 2006, 160, 1-40.

57. Dubey, S.; Ganeshpurkar, A.; Shrivastava, A.; Bansal, D.; Dubey, N. Rutin exerts antiulcer effect by inhibiting the gastric proton pump. Indian J. Pharmacol. 2013, 45, 415-417.

58. De Lira Mota, K.S.; Dias, G.E.N.; Pinto, M.E.F.; Luiz-Ferreira, Â.; Monteiro Souza-Brito, A.R.; Hiruma-Lima, C.A.; Barbosa-Filho, J.M.; Batista, L.M. Flavonoids with gastroprotective activity. Molecules 2009, 14, 979-1012.

59. Mimić-Oka, J.; Simić, D.V.; Simić, T.P. Free radicals in cardiovascular diseases. FACTA UNIVERSITATIS Ser.: Med. Biol. 1999, 6, 11-22.

60. Aditi, Mahajan, N.; Rawal, S.; Katare, R. An insight in to the pathogenesis of diabetic vascular diseases: Role of oxidative stress and antioxidants. Pharm. Anal. Acta 2013, 4, 273, doi:10.4172/2153-2435.1000273.

61. Cooke, M.S.; Evans, M.D.; Dizdaroglu, M.; Lunec, J. Oxidative DNA damage: Mechanisms, mutation, and disease. FASEB J. 2003, 17, 1195-1214.

62. Sharma, J.N.; Al-Omran, A.; Parvathy, S.S. Role of nitric oxide in inflammatory diseases. Inflammopharmacology 2007, 15, 252-259.

63. Sultana, R.; Perluigi, M.; Butterfield, D.A. Lipid peroxidation triggers neurodegeneration: a redox proteomics view into the Alzheimer disease brain. Free Radic. Biol. Med. 2013, 62, 157-169. 
64. Baillet, A.; Chanteperdrix, V.; Trocmé, C.; Casez, P.; Garrel, C.; Besson, G. The role of oxidative stress in amyotrophic lateral sclerosis and Parkinson's disease. Neurochem. Res. 2010, 35, $1530-1537$.

65. Wangensteen, H.; Samuelsen, A.B.; Malterud, K.E. Antioxidant activity in extracts from coriander. Food Chem. 2004, 88, 293-297.

Sample Availability: Samples of the extracts from Vernonia kotschyana roots are available from the authors.

(C) 2014 by the authors; licensee MDPI, Basel, Switzerland. This article is an open access article distributed under the terms and conditions of the Creative Commons Attribution license (http://creativecommons.org/licenses/by/4.0/). 